\title{
MUKANA MUUTOKSESSA
}

Kirja-arvostelu teoksesta: Muutoksen tekijät hyvässä seuras-

sa: Suomen tieteellinen kirjastoseura 1970-2010. Toim. Tuula

Ruhanen ja Marja Sarvilinna. Suomen tieteellinen kirjastoseura 2018.

Suomen tieteellinen kirjastoseura (STKS) saavuttaa tänä vuonna

kunnioitettavan 90 vuoden iän. Juhlavuoden kunniaksi seura päätti julkaista historiikkinsa neljältä vuosikymmeneltä vuosilta 1970-2010. Muutoksen tekijät -teos luo laajan ja värikkään katsauksen tieteellisten kirjastojen kehitykseen ja yhteistyöhön niin STKS:ssä kuin sen ulkopuolellakin.

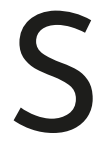

uurin osa tieteellisistä kirjastoista on kautta aikojen palvellut emo-organisaatioitaan - yliopistoja, ammattikorkeakouluja ja tutkimuslaitoksia. Kehittyäkseen ammatillisesti niiden työntekijät ovat tarvinneet yhteistyötä muiden kirjastojen kanssa. STKs:n rooli kollegiaalisten verkostojen luojana, ammatti-identiteetin vahvistajana sekä ammatillisen kehittymisen ja keskustelun foorumina on ollut merkittävä.

Toiminnan alkuvaiheessa Suomen tieteelliseen kirjastoseuraan ei päässyt kuka tahansa, vaan jäsenyyteen vaadittiin seuran hallituksen jäsenen suositus. I970-luvulla seuraan liittyminen vapautui ja politiikka muuttui valikoinnista rekrytointiin. Kirjastonhoitajien lisäksi muutkin kirjastotyöntekijät toivotettiin tervetulleiksi - myös opiskelijoita tavoiteltiin mukaan toimintaan. Uusia jäseniä hankittiin aktiivisesti kampanjoimalla. Kuudensadan jäsenen raja ylitettiin I990-lu- vulla, minkä jälkeen jäsenmäärässä on ollut hienoista laskua. Jäsenkunta ulottui kaikille kirjastosektoreille. Tieteellisten kirjastojen organisaatioista STKS onkin laajin alan henkilökuntaa kokoava toimija Suomessa.

\section{Jäsenkokouksista koulutusten järjestämiseen}

STKS:n toiminnan muodot ovat vaihdelleet historian saatossa. Alkuvaiheessa seuran kokoukset olivat yleisötilaisuuksia, joissa esitelmöitiin ja keskusteltiin ammatillisesti kiinnostavista aiheista - tiloja näihin tilaisuuksiin tarjosivat kirjastojen tuolloiset yhteistyökumppanit Akateeminen ja Suomalainen kirjakauppa. Vähitellen kuitenkin jäsenkokoukset jäivät pois. Esitelmät ja keskustelu siirtyivät seuran järjestämiin koulutuspäiviin, joihin yleensä osallistuttiin työajalla ja työnantajan kustannuksella. Työskentely seuran jaostoissa ja työryhmissä on ollut monelle tärkeä tilaisuus oppia vaikuttamista ja hallin- 
nollisia taitoja. Kansainvälistä toimintaa ovat olleet retket ja opintomatkat, edustukset kansainvälisissä järjestöissä ja kansainväliset seminaarit Suomessa. Seuran äänenkannattaja Signum-lehti on yhdistänyt jäsenistöä ja tuonut kaikille tuoreita kuulumisia alan kehityksestä.

Samaan aikaan kun sTKs on luonut pohjaa yhteistyölle, on tieteellisten kirjastojen asemaa ja kehitystä pyritty turvaamaan myös hallinnollisten ratkaisujen avulla. Tieteellisen informoinnin neuvosto (Tinfo) ja keskuskirjastojärjestelmä olivat I960-I980-luvuilla yrityksiä luoda ohjausjärjestelmiä tieteellisten kirjastojen kirjavalle kentälle. Näistä ei kuitenkaan tullut pysyviä rakenteita. I990-luvulla yhteistyö sai uusia muotoja, kun yliopistokirjastot järjestäytyivät Yliopistokirjastojen neuvostoksi ja niiden vanavedessä myös ammattikorkeakoulujen kirjastot ja erikoiskirjastot perustivat omat neuvostonsa.

\section{VTLS, Finmarc, Linnea2, Voyager}

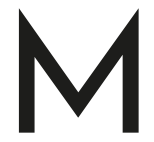

erkittävimmät ja kauaskantoisimmat yhteiset ponnistukset tieteellisissä kirjastoissa on tehty kirjastojärjestelmien käyttöönotoissa ja kehittämisessä. I980-luvun lopulla vTLS- järjestelmän hankintaa koordinoi tuolloin opetus- ja kulttuuriministeriön alaisena toiminut
Tieteellisten kirjastojen ATK-yksikkö. Kirjastojen yhteistyö Linnea-hankkeessa mahdollisti suurasiakkaan aseman lisäksi myös Finmarc-formaatin ja yhteistietokannan kehittämisen.

Yhteistyö jatkui Linnea2-projektissa 2000-luvun alussa, kun Voyager-järjestelmää hankittiin. Järjestelmien ja formaattien kehittämisessä yhteistyö on siis ollut voimaa. Sen edut ovat olleet mittavat myös hankinnoissa, varsinkin sähköisten julkaisujen aikakaudella, kun e-lehtien hankinnat on voitu keskittää FinELib-konsortiolle. Myös sisällönkuvailukäytänteitä, kokoelmakarttaa ja informaatiolukutaitoa on edistetty yhdessä suunnitellen ja keskustellen. Seuran koulutukset ja muu toiminta ovat tukeneet ja edistäneet näitä muutoksia.

\section{Tuokiokuvia arkistoista, haastatteluista ja Signumista}

Muutoksen tekijät -kirjan lähdeaineistoksi on koottu seuran omien arkistojen ja Signum-lehden lisäksi mittava haastatteluaineisto. Myös monet sen artikkeleista ovat alan keskeisten vaikuttajien kirjoittamia. Ratkaisu tuo historian mainiolla tavalla lähelle lukijaa: paikoin voi suorastaan aistia tilaisuuksien tunnelman.

Elävien tuokiokuvien lisäksi kirja sisältää ilahduttavan paljon tietoa tieteellisten kirjastojen toiminnasta ja avaa lukijalle kirjastotyön kehityksen 
käännekohtia. Ansioistaan huolimatta teos ei poista tarvetta tutkimukseen perustuvalle tieteellisten kirjastojen kirjastohistorialle. Tieteelliset kirjastot ansaitsisivat samankaltaisen laajan yleisesityksen, jonka Ilkka Mäkinen on julkaissut yleisten kirjastojen historiasta. Toivokaamme, että sTKs:n historiikki inspiroisi gradujen ja väitöskirjojen tekijöitä ja muita tutkijoita näiden kysymysten äärelle!

Kustannustoimittajan työpanos olisi ollut kirjalle eduksi: Näin olisi saatu yhtenäistetyksi kirjan rakennetta sekä karsittua pieniä lipsahduksia ja päälekkäisyyksiä, joita kirjoittajilla helposti kiireessä syntyy. Kirjavat graafiset ratkaisut vaikeuttavat hieman lukukokemusta. Lukijan kannalta olisi ollut selkeä ratkaisu sijoittaa luvussa neljä olleet toimihenkilöluettelot kirjan loppuun. Historiateoksessa erillisestä henkilöhakemistosta olisi paljon iloa. Ammattitaitoinen toimittaja olisi myös huomannut pienet lipsahdukset, kuten sen, että esipuheessa kirjan mainitaan olevan 50-vuotishistoriikki, vaikka tarkastelu kattaa vain vuodet I970-20 Io.

\section{STKS:Ilä on vielä paljon} tehtävää!

Muutoksen tekijät päättyy vuoteen 20 Iо. Viimeisinä yhdeksänä vuotena on tapahtunut paljon. Erikoiskirjastoja ja ammattikorkeakoulukirjastoja on laitoksia yhdistettäessä lakkautettu. vasti muuttumassa. Muutoksen taustalla on maailman sähköistyminen: sähköiset aineistot ovat vallanneet alaa painetuilta kokoelmilta, ja kirjastoille on tullut uusia velvoitteita perinteisen kokoelmatyön ja asiakaspalvelun rinnalle. Avoin tiede edellyttää uusia palveluita ja uudenlaista osaamista.

Kirjastot ovat ottaneet aiempaa aktiivisen roolin tieteellisen julkaisutoiminnan kentällä ja ryhtyneet kehittämään tutkimusdatapalveluita. Yhteinen kirjastojärjestelmä on tullut tiensä päähän. Sinänsä tämä on mainio ajankohta luoda katsaus menneitten vuosien yhteistyöhön ja nostaa esiin kysymys, kuinka tieteelliset kirjastot voivat yhdistyä tieteen, sivistyksen ja ennakkoluulottomien ratkaisujen puolestapuhujiksi myös tulevaisuudessa. Seuralla on vielä paljon tehtävää!

\author{
Tietoa kirjoittajasta \\ JohanNa LiLJA \\ palvelujohtaja \\ Helsingin yliopiston kirjasto \\ johanna.e.lilja@helsinki.fi
}

